\title{
Development of regional economic systems under the impact of financial decentralization: display, challenges and new opportunities
}

\author{
Halyna Voznyak \\ Department of Regional Financial \\ Policy \\ M. I. Dolishniy Institute of Regional \\ Research of NAS of Ukraine \\ Lviv, Ukraine \\ gvoznyak@gmail.com
}

\author{
Olena Panukhnyk \\ Department of Economics and Finance \\ Ternopil Ivan Puluj National Technical \\ University \\ Ternopil, Ukraine \\ panukhnyk@gmail.com \\ Nazariy Popadynets* \\ Department of Regional Economic \\ Policy \\ M. I. Dolishniy Institute of Regional \\ Research of NAS of Ukraine \\ Lviv, Ukraine \\ popadynets.n@gmail.com
}

\author{
Hryhoriy Khymych \\ Department of Radio Engineering \\ Systems \\ Ternopil Ivan Puluj National Technical \\ University, Corporation «Science Park \\ «Innovation-Investment Cluster of the \\ Ternopil Region» \\ Ternopil, Ukraine \\ sciencepark.t@gmail.com
}

\begin{abstract}
The ongoing processes of authorities' and public finances' reforming in Ukraine stipulate the real opportunities to increase the resources of sustainable development of regional economic systems. At the same time, global practice shows that financial decentralization processes produce contradictions and development risks for a country and its regions, preventing the achievement of designated goals. These aspects explain the growing interest in scientific and practical problems of defining the influence of financial decentralization on the development of regional economic systems. The methods of systemic-structural and functional analysis and economicmathematical modeling were applied in the process of the research of financial decentralization's influence on the development of regional economic systems. The analyzed practices of financial decentralization reform in the world show that there is no unified model of its implementation. The paper outlines the problems the researchers faced in the course of empirical studies to define the patterns of impact the financial decentralization has on the processes of development of various economic systems. Based on the logarithmic model of multiple linear panel data regression, the paper verifies the hypothesis about the influence of decentralization on economic growth of Ukrainian regions in 2017-2018. Its impact on economic growth of regions by revenues and expenditures as well as the growth of local budgets' own revenues is estimated as positive. Strong negative influence of interbudgetary transfers on independent variable is experimentally confirmed. Based on the results of conducted empirical research, the paper suggests the recommendations regarding the imperatives the policy of sustainable growth of Ukrainian regions should be developed on.
\end{abstract}

Keywords-financial decentralization, regional economic systems, local budgets, panel data, local governments, economic growth

\section{INTRODUCTION}

Financial decentralization reform is one of important reforms in many countries (including the developing ones) due to the fact that by its nature it is designated to secure the redistribution of revenue sources and liabilities among the levels of authorities and the most efficient funding of both social standards and projects of subordinate territories' development. The final goal of financial decentralization reform is to use efficiently budget funds and to create proper financial conditions to secure the execution of liabilities by local authorities and self-governments and what is most important - to form financially capable territorial communities able to maintain the provision of qualitative public services. Usually, the defined goal is achieved by accomplishment of the range of tasks, the most essential of which are the following: forming balanced local budgets; increasing own financial capacity of administrative and territorial units at basic level; clear distribution of liabilities on the subsidiarity level; improvement of the efficiency of use of financial resources and stimulation of communities' sustainable development.

We should mention that the manifestations of various forms of financial decentralization can be observed almost in all economic systems without exceptions; however, its efficiency and level of impact on socio-economic development of territories depends on how the approaches to its implementation are formed. It is in the first place.

Secondly, financial decentralization of regional economic systems is a priori complex process of distribution: of functions, liabilities, financial resources and responsibility for their use. Preconditions of its implementation always stipulate various goals and ways of their achievement: whether it is the expanding of local governments' financial capacities with the view to improve the efficiency of providing social services (e.g. Denmark, Sweden, Finland) or strengthening of local democracy (countries of Eastern Europe). Eventually, administrative and territorial units gain the "new" status in making managerial decisions. Depending on the nature of interaction between public authorities, the forms of financial decentralization manifestation will have their advantages 
over decentralization at least because local autonomies enable solution of social problems and meeting the interests of residents possible due to transparent areas of living activity.

Thirdly, global practices confirm that, on the one hand, financial decentralization means positive changes that strengthen the ground for sustainable growth in a long-term perspective and, on the other hand, deepening financial decentralization processes causes the contradictions and development risks for a country in general and its regions in particular, eventually preventing the achievement of designated goals.

For Ukraine, the orientation on European vector of regional economic systems' development (confirmed by ratification of EU-Ukraine Association Agreement) means that emphasis will shift to inclusiveness, innovations, smart specialization and most important - development of regions' economic capacity based on financial decentralization. On the other hand, synthetic nature of Ukrainian reforms, which began in 2014, has boosted the problem of sustainability of regional economic systems' development as far as successful reforms are the key to improvement of welfare and quality of life.

In the context of abovementioned, practical importance of the research of defined problems is stipulated by social discussion on finding the unequivocal (positive or negative) impact of financial decentralization on the development of regional economic systems, which should lead to individual well-being in a long-term perspective.

The article aims to measure the directions of financial decentralization's impact on the development of regional economic systems and to determine the level of its strengthening.

\section{THE AIM AND METHOD USED}

The processes of financial decentralization in Ukraine are the object of research in the article. Fundamental provisions and principles of fiscal decentralization and budget federalism theory serve as methodological basis of the research. The complex of specific cognitive methods, namely systemic-structural and functional analysis and economic-mathematical modeling, secured the opportunity to realize the integrity of scientific research.

Lately the issues of financial decentralization are the subject of expert and scientific research in the countries of Eastern Europe, OECD, China, Malaysia, and most recently - in Ukraine. The growing interest in these matters is stipulated in the first place by the importance of financial decentralization "phenomenon" as an instrument of development regulation in economic systems. The search for the answers to the urgent question has become the integral part of social discussions, including if there is a relation between financial decentralization and territories' economic growth, level of budget independence of regional authorities and inflation, state debt and level of budget system balance; if financial decentralization actually contributes to reduction of expenditures on national level with their simultaneous growth on lower levels; if internal regional competition caused by financial decentralization promotes the growth of own revenues, etc. Meanwhile, in order to verify (or reject) the hypothesis, the researchers analyzed and adapted various models of economic growth and used all possible empirical methods and econometric specifications $[1 ; 2]$.

The conclusions made on the basis of theoretical and empirical research on the subject turned out to be not clear and ambiguous, sometimes even diametrically opposed.

Indeed, American scientists J. Boex and B. Edwards [3], researched the directions and level the financial decentralization influences the economies of twenty nine developing countries. They concluded that empirical research considering only decentralized expenditures for the delegated competences of local self-governments did not show the cohesive "picture" of financial decentralization reform. The authors argued that such conclusions were somewhat biased. They made an alternative suggestion to include all expenditures transferred to local level in the model. The research resulted in conclusion about the limited nature of decentralization's influence on economic growth of selected countries. There are different explanations: from passive decision making among local self-governments to inefficient distribution of financial resources and strengthening of local elites' impact.

Generalizations of these authors (B. Edwards, S. Yilmaz, and J. Boex) [4] in the course of analysis of financial decentralization reform in the country at war (Sierra-Leone) are diametrically opposed. The authors confirmed that after the long years of conflict the decentralization had revitalized the economy of the Republic and had strengthened the democratic standards. However, the horizontal development asymmetries had not been eliminated by implementing only the decentralization reform. Therefore, overcoming of horizontal asymmetries in providing social services as the major decentralization mission had also failed.

The research conducted on the example of OECD countries (H. Blöchliger, B. Égert and K. Fredriksen) [5] testifies to the broad spectrum of financial decentralization impact on the development of economic systems. Indeed, the authors established by experiments that: investment in human capital is more efficient in more decentralized countries and decentralized budget policy positively influences the growth of economic capacity not only through investment in technology but also due to increasing human capital; revenues decentralization is also higher than expenditures decentralization. Fiscal decentralization is the positive incentive of territorial development because it provides local self-governments with an opportunity to increase capital investment, adjust the composition of expenditures and increase investment in socially oriented sectors, etc. Regarding educational services, decentralized governing bodies provide them more efficiently. Majority of empirical research prove that decentralization in education positively impacts the success (of pupils/students), although the consequences are very ambiguous for primary education.

Recently a new approach to the development of economic systems on the principles of inclusive growth has been gaining increasing relevance. It stipulates equal opportunities for all population groups (in education, healthcare, security, etc.) and fair distribution of benefits in society, which should in its turn promote the growth of wellbeing of population. New long-term strategies of the countries' development under the concept should be based 
on productive employment. By the way, the strategy of inclusive growth is the basis of economic reforms of Chinese government aiming at global innovative leadership and innovative nation. Based on the research [6], it is possible to contemplate challenges and problems the countries of Asia (China, Indonesia, Japan) face in solving the inclusive growth issues while implementing the fiscal decentralization reform.

Spain (according to many experts) is the example of solution of budget federalism problems. The special feature of local governance organization in the country is the principle of autonomy enshrined in constitution, which provides that all territorial units forming the system of administrative and territorial structure of the country have financial independence in solution of their issues. Empirical research on the example of Spanish regions brought D. Cantarero and P. Perez Gonzalez [7] into conclusions about the lack of significant relation between the growth of GDP per capita and decentralization of expenditures. On the other hand, essential relation is peculiar to revenues decentralization.

Therefore, in our opinion, the presented review of conclusions provided by research is explained, on the one hand, by use of different approaches and methodics of financial decentralization evaluation (not all publicly available indicators can be considered to be the exponents of real budget independence and high share of local budgets in the consolidated one does not always mirror the broad autonomy of local authorities), and, on the other hand, by appropriate choice of dependent variable that defines the reliability level of obtained results.

Despite substantial developments in global science regarding this matter, the issue of extension of local governments' financial autonomy, establishing the relation between financial decentralization and development of regional economic systems in Ukraine and finding its impact on the quality and efficiency of budget policy have not been widely discussed and are empirically underexamined. Therefore, they need additional study.

\section{RESEARCH RESULTS}

Scientific hypothesis about the influence of financial decentralization on the growth of regional economic systems in Ukraine by the defined directions will be verified based on the panel data models generally presented as [8]:

$$
Y_{i t}=\alpha_{i}+X_{i t} \beta_{i t}+\varepsilon_{i t}
$$

where $Y_{i t}$ - the rate under research (dependent variable) for $i$ object in time $t ; i=1, \ldots, N, t=1, \ldots, T$; $X_{i t=}^{\prime}\left(X_{1 i t}, X_{2 i t}, \ldots X_{k i t}\right)$ - vector of independent variables (factors); $\varepsilon_{i t}$ - deviation of $\boldsymbol{i}$ object in time $t ; \alpha_{i}$ - scalar that shows the impact of factors that are specific from unit to unit but unchanged over time; $\beta_{i t}$ - parameters of model that measure the marginal effects of independent variables on the dependent one, meaning that the effects of the change of $X$ are the same for all units and in all observations. In case that $\beta_{i t}$ are stable for all values of $t$ and $i$, the (1) becomes the usual regression model with multiple panel data:

$$
Y_{i t}=\alpha+\beta_{1} X_{1 i t}+\beta_{2} X_{2 i t}+\ldots+\beta_{k} X_{k i t}+\varepsilon_{i t},
$$

where $Y_{i t}$ - the value of the parameter under research (dependent variable) for $i$ object in time $t ; \alpha$ and $\beta_{j}$ - the unknown model parameters; ${ }^{X}$ jit - the value of the factor for $i$ object in time $t ; \varepsilon_{i t}$ - the deviation, wherein $i=1, \ldots, N$, $t=1, \ldots, T ; j=1, \ldots, k$. Estimation of the model parameters is the same as with classical multiple regression models.

We will test the hypothesis for the relation between financial decentralization and the development of regional economic systems, based on the models with fixed and variable effects according to the Figure 1.

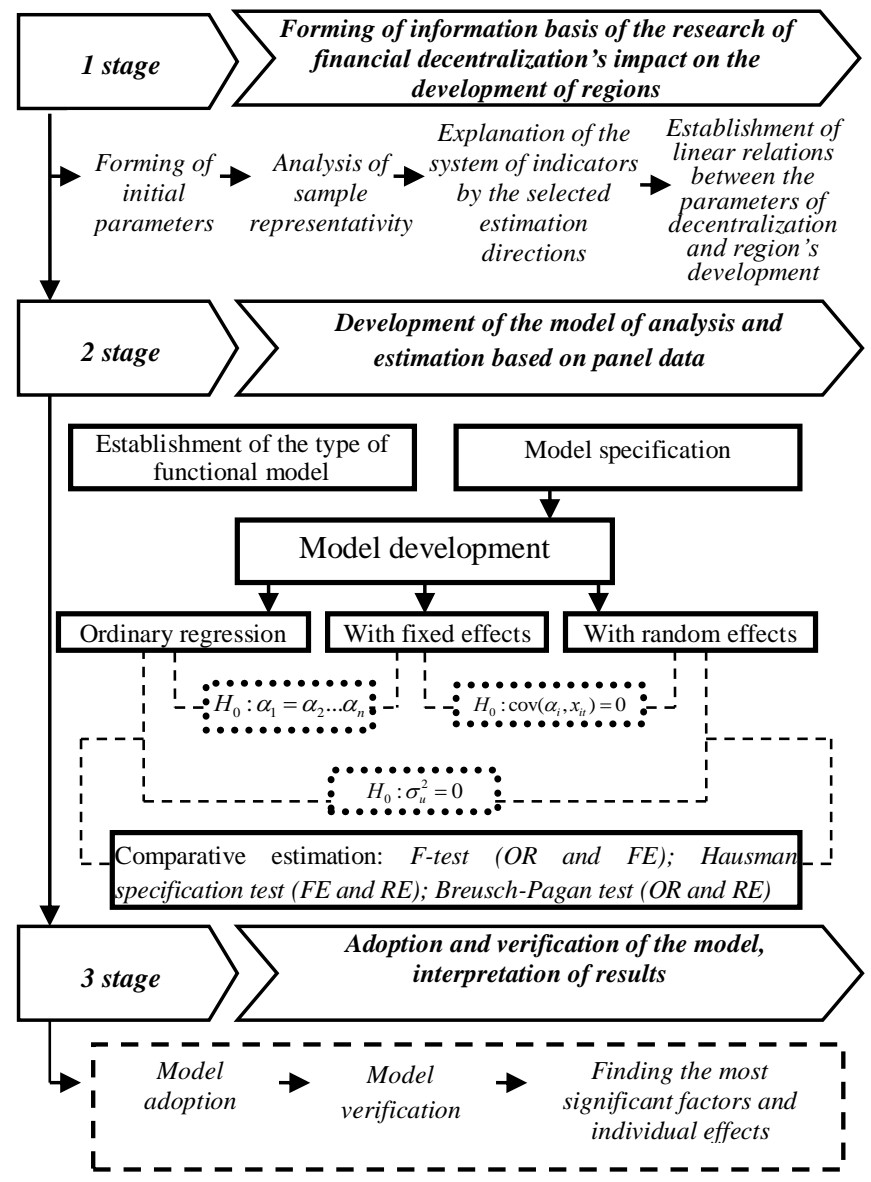

Fig. 1. Sequence of estimation of financial decentralization's impact on the development of regions

Source: developed by authors

Modeling was carried out based on the formed panel data across all Ukrainian regions (excluding the occupied territories of Donetsk and Luhansk oblasts) for the period 2017- 2018 using the program package Gretl [9].

The following logarithmic model of multiple linear regression was applied:

$$
\ln Y_{i t}=\alpha+\beta \ln D_{i t}+\gamma \ln K_{i t}+\varepsilon_{i t}
$$

where $\ln Y_{i t}$ - the GRP per capita, the value of the parameter under research (dependent variable) for $i$ object in time $t$, wherein $i=1, \ldots, 25, t=2 ; D_{i t=}\left(D_{1 i t}, D_{2 i t}, D_{3 i t}, D_{4 i t}, D_{5 i t}\right)$ 
- the vector of independent variables: $D_{\text {lit }}$ - the share of local budgets revenues in the revenues of consolidated budget (without transfers); $D_{2 i t}$ - the share of local budgets expenditures in the expenditures of consolidated budget (without transfers); $D_{3 i t}$ - the share of inetrbudgetary transfers in the revenues of local budgets; $D_{4 i t}$ - the share of tax revenues in the revenues of local budgets; $D_{5 i t}$ - the share of own revenues in the revenues (without transfers); $K_{i t}$ the vector of additional variables ( $K_{1 t}$ - unemployment, $K_{2 t}$ inflation, $K_{3 t}$ - the share of capital investment in GRP, $K_{4 t}$ the share of local taxes in GRP, $K_{5 t}$ - the single tax in the revenues of local budgets, $K_{6 t}$ - the subventions for socioeconomic development of certain territories); $\varepsilon_{i t}$ - the deviation of $i$ object in time $t ; \alpha, \beta$ and $\gamma$ - the estimated model parameters. The authors are aware that the model is somewhat restricting as it stipulates the same behavior for all sample objects in any time. The use of logarithmic variables in the estimation of multiple linear regression, in our opinion, will make it possible to approximate the distribution of regression residues to normal.

Having carried out the modeling for three cases (multiple regression, with fixed and random effects) across all independent variables and having performed their pairwise comparison based on statistical tests (BreuschPagan and Hausman), the authors establish that the multiple regression model is adequate for this data set. Model parameters were estimated by the method of the least squares. Thus, analytical display of the model by the direction of revenues decentralization $\left(\ln D_{1}\right)$ is:

$$
\ln Y_{i t}=9.10027+0.617580 \ln D_{1 i t}+\gamma \ln K_{i t}+\varepsilon_{i t}
$$

The results of calculations by this direction are presented in Table 1. It shows that: independent variable $\left(\ln D_{1}\right)$ explains the dependent variable $\left(R^{2}=0.78\right)$, functional connection is strong, therefore, in 2017-2018 the impact of decentralization of local budgets' revenues on the increase of GRP per capita was growing in Ukraine, regression coefficient at $D_{1}$ is of positive value and statistical significance is high ( ${ }^{* * *} p \prec 0.01$; ), the model is qualitatively acceptable.

TABLE I. RESULTS OF ESTIMATION OF MULTIPLE REGRESSION MODEL FOR REVENUES DECENTRALIZATION

\begin{tabular}{|l|c|c|c|c|c|}
\hline & Coefficient & $\begin{array}{c}\text { Standard } \\
\text { deviation }\end{array}$ & t-statistic & P-value & \\
\hline const & 9,10027 & 0,932794 & 8,5431 & $<0,0001$ & $* * *$ \\
\hline $\ln D_{1}$ & 0,617580 & 0,0752276 & 9,5209 & $<0,0001$ & $* * *$ \\
\hline $\ln K_{1}$ & 0,030129 & 0,28521 & 0,2488 & 0,8134 & \\
\hline $\ln K_{2}$ & $-0,530369$ & 0,0845196 & $-1,7280$ & 0,1096 & $* *$ \\
\hline $\ln K_{3}$ & 0,484001 & 0,0631570 & 0,3201 & 0,0401 & $* * *$ \\
\hline $\ln K_{4}$ & 0,210536 & 0,20729 & $-1,2525$ & 0,0024 & $* * *$ \\
\hline $\ln K_{5}$ & 1,71648 & 0,430251 & 1,6402 & 0,0011 & $* * *$ \\
\hline $\ln K_{6}$ & 0,313097 & 0,04603455 & 1,2963 & 0,1538 & \\
\hline \multicolumn{7}{|c|}{$p \prec 0.10 ;{ }^{* *} p \prec 0.05 ;{ }^{* * *} p \prec 0.01$} \\
\hline
\end{tabular}

Authors' calculations using the statistics package Gret
We should note that the received result agrees with general tendencies in Ukraine. Indeed, the first stage of financial decentralization reform in Ukraine reveals the substantial growth of revenues to local budgets (Figure 2).

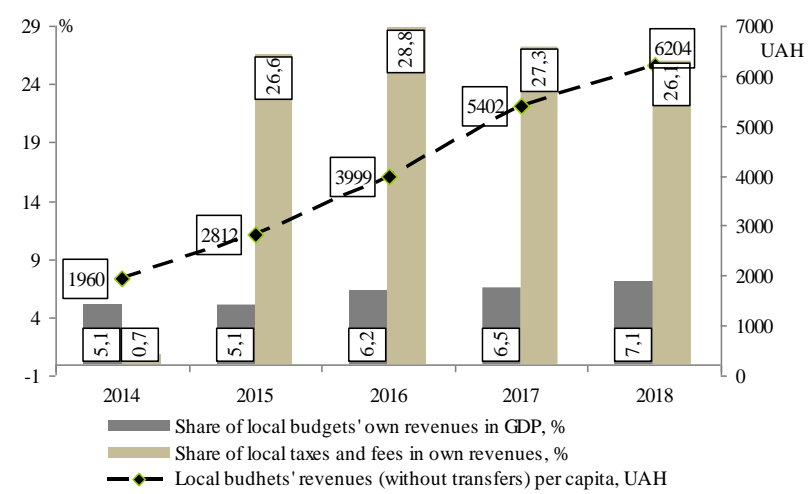

Fig. 2. Dynamics of local budgets' revenues in Ukraine, 2015-2018

Source: developed based on data https://decentralization.gov.ua/finance/analityka-ta-monitorynhy

Having done the same steps for all defined independent variables, we received the results of panel regression analysis for specifications of all models characterizing the impact of financial decentralization on the development of regional economic systems by the chosen directions (Table 2).

Table 2 analysis gives us ground to argue that positive results of expenditures model testing have turned out to be expected and predictable $\left(R^{2}=0.607\right)$, same as in the previous period. Strong negative impact of interbudgetary transfers on the development of regional economic systems ( $R^{2}=0.811$ ), unfortunately, corresponds to the reals economic situation in Ukraine.

TABLE II. RESULTS OF MULTIPLE REGRESSION MODEL ESTIMATION FOR 2017-2018

\begin{tabular}{|c|c|c|c|c|c|}
\hline & $\ln D_{1}$ & $\ln D_{2}$ & $\ln D_{3}$ & $\ln D_{4}$ & $\ln D_{5}$ \\
\hline \multirow[t]{2}{*}{ Var } & $0.617580^{* * * *}$ & $0,89712^{* *}$ & $-2.51362 * * *$ & $5.09669 * * *$ & $2.73865^{*}$ \\
\hline & $(9.5209)$ & $(3.3453)$ & $(-7.5415)$ & $(5.1297)$ & $(2.5150)$ \\
\hline \multirow[t]{2}{*}{$\ln K_{1}$} & 0.030129 & -0.095981 & $-0.541095 *$ & $-1.1247 * *$ & -0.512671 \\
\hline & $(0.2488)$ & $(0.1488)$ & $(-2.0191)$ & $(-2.2300)$ & $(-1.6102)$ \\
\hline \multirow[t]{2}{*}{$\ln K_{2}$} & $-0.530369 * *$ & -0.134548 & -0.088479 & 0.108158 & 0.051460 \\
\hline & $(-1.7280)$ & $(-0.1258)$ & $(-1.1490)$ & $(1.2327)$ & $(0.1250)$ \\
\hline \multirow[t]{2}{*}{$\ln K_{3}$} & $0.484001 * *$ & 0.24433 & $-0.525934 * *$ & -0.11097 & -0.001395 \\
\hline & $(0.3201)$ & $(0.7839)$ & $(-2.7171)$ & $(-0.3763)$ & $(-0.1116)$ \\
\hline \multirow[t]{2}{*}{$\ln K_{4}$} & $0.210536 * * *$ & -0.640120 & $-1.45233^{* *}$ & 0.99678 & 0.743911 \\
\hline & $(-1.2525)$ & $(-1.0006)$ & $(-3.1625)$ & ()1.5038 & $(0.9640)$ \\
\hline \multirow[t]{2}{*}{$\ln K_{5}$} & $1.71648 * * *$ & $1.71501 * *$ & $1.24117^{*}$ & 1.22475 & 0.417311 \\
\hline & $(1.6402)$ & $(2.0091)$ & $(2.6249)$ & ()1.9745 & $(0.3390)$ \\
\hline \multirow[t]{2}{*}{$\ln K_{6}$} & 0.313097 & 0.151750 & $0.115834 * *$ & -0.015867 & -0.071334 \\
\hline & $(1.2963)$ & $(0.6408)$ & $(2.9868)$ & $(-0.0768)$ & $(-0.7776)$ \\
\hline \multirow[t]{2}{*}{ const } & $9.10027 * * *$ & 8.51559 *** & $19.0475 * * *$ & $14.0038 * * *$ & $5.00181^{*}$ \\
\hline & $(8.5431)$ & $(5.2761)$ & (11.001) & $(2.3241)$ & $(1.2117)$ \\
\hline$R^{2}$ & 0.78 & 0.607 & 0.811 & 0.791 & 0.599 \\
\hline \multicolumn{6}{|c|}{$p \prec 0.10 ; \quad p \prec 0.05 ; \quad{ }^{* * * *} \quad p \prec 0.01$} \\
\hline
\end{tabular}

Authors' calculations using the statistics package Gretl

Local budgets and redistribution of state ones definitely play an important role in the growth of these positive trends (which is fairly well confirmed by the results of modeling with high value of $\left(K_{4 t}\right)$. Herewith, we should recognize that 
own revenues of local budgets have unfortunately failed to reach the level of European countries. However, growing financial resources of local budgets provided the regions with an opportunity to direct funds to the development of their territories and to increase the volumes of capital investments (positive value at $\left(K_{3 t}\right)$ is the confirmation).

Excessive transfer dependence still remains in the system of regions' local finances despite the growing recent financial decentralization processes. It is confirmed by the growth of local budgets' revenues in Ukrainian regions, which is secured by transfers for more than a half [9]. Distribution of basic government grants across the administrative-territorial units also testifies to the growth of transfer dependence (Figure 3).

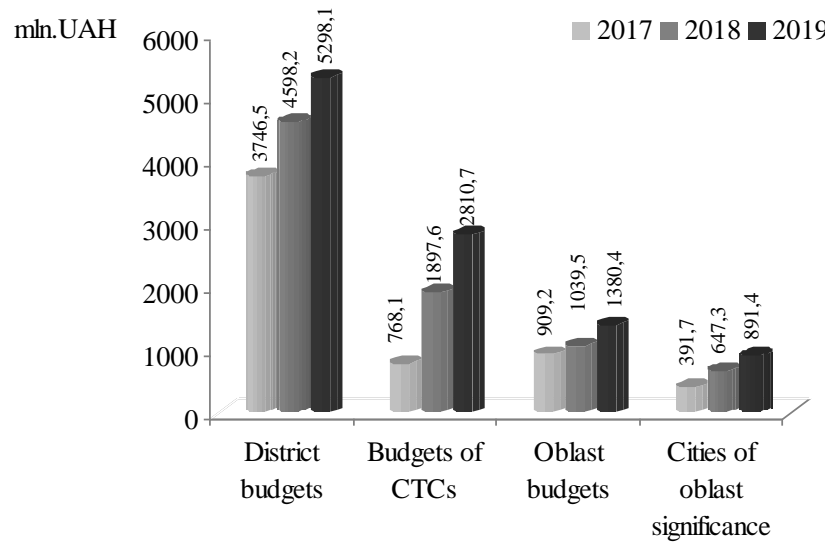

Fig. 3. Distribution of basic government grants across administrative and territorial units of Ukraine, 2017-2019

Spurce: developed based on the data of the State Treasury Service of Ukraine. URL: https://data.gov.ua/dataset/zvit_kazna

By the way, if in 2018 the basic government grant in the amount of 8.2 billion UAH was designated for 931 local budgets out of 1288 being directly related (17 oblasts, 52 cities, 363 regions, 499 CTCs), in 2019 the amount was 10.4 billion UAH for 935 local budgets (19 oblasts, 53 cities, 353 regions, 510 CTCs). It is worth noting that $70 \%$ of consolidated territorial communities created in 2015-2019 receive basic government grants, therefore they are insolvent and cannot guarantee the provision of qualitative public services. On the other hand, the abovementioned provides the ground to argue that realization of communities' development programs as the basis of sustainable growth of regions' economy has not become massive in scope yet, which in fact is the negative feature of financial decentralization. In this context, it is necessary to mention another negative aspect of the reform, which is directly related to the system of interbudgetary relations and which has clearly shown itself in the period of the reform implementation in Ukraine. It is about the misbalances between the volumes of liabilities delegated to the basic level and the volumes of delegated financial resources. In fairness, we should admit that the problem of clear delineation of functions and responsibilities among the levels of authority used to be peculiar to the EU Member States as well [10].

Another aspect of the conducted research that draws attention is the essential growth of the role of own income in stimulation of the development of regional economic systems. The results of conducted empirical research show the considerable relation between the independent variable $\left(\ln D_{5}\right)$ and GRP per capita. Unlike the previous period, in 2017-2018 the relation is characterized by considerable positive influence $\left(R^{2}=0.559\right)$, although statistical significance is not high $\left({ }^{*} p \prec 0.10\right)$. This offers a hope that the growth of local budgets' own income is becoming (although with very slow paces) the momentum of territories' economic development.

Growing financial decentralization by tax revenues in 2017-2018 is fundamentally different than it was in the previous years: the connection between the dependent variable and the share of tax revenues in local budgets' revenues is strong ( $R^{2}=0.791$ ). Positive coefficient at the investigated parameter $\ln D_{4}$ shows positive changes and positive value of the regression intercept shows positive impact of financial decentralization on economic growth of Ukrainian regions by this direction.

Statistical models of influence that enable prognosis of the values of dependent variables for the selected independent variables can be presented the following way (Table 3).

TABLE III. MODELS OF FUNCTIONAL DEPENDENCIES BETWEEN FINANCIAL DECENTRALIZATION AND DEVELOPMENT OF REGIONAL ECONOMIC SYSTEMS IN 2017-2018

\begin{tabular}{|l|l|l|}
\hline $\begin{array}{c}\text { Estimation } \\
\text { direction }\end{array}$ & \multicolumn{1}{|c|}{ Equation } & \multicolumn{1}{|c|}{$\begin{array}{c}\text { Value } \\
R^{2}\end{array}$} \\
\hline $\ln D_{1}$ & $\ln Y_{i t}=9.10027+0.617580 \ln D_{1 i t}+\gamma \ln K_{i t}+V_{i}+\varepsilon_{i t}$ & 0.78 \\
\hline $\ln D_{2}$ & $\ln Y_{i t}=8.51559+0.89712 \ln D_{2 i t}+\gamma \ln K_{i t}+V_{i}+\varepsilon_{i t}$ & 0.607 \\
\hline $\ln D_{3}$ & $\ln Y_{i t}=19.0475-2.51362 \ln D_{3 i t}+\gamma \ln K_{i t}+V_{i}+\varepsilon_{i t}$ & 0.811 \\
\hline $\ln D_{4}$ & $\ln Y_{i t}=14.0038+5.09669 \ln D_{4 i t}+\gamma \ln K_{i t}+V_{i}+\varepsilon_{i t}$ & 0.791 \\
\hline $\ln D_{5}$ & $\ln Y_{i t}=5.00181+2.73865 \ln D_{5 i t}+\gamma \ln K_{i t}+V_{i}+\varepsilon_{i t}$ & 0.599 \\
\hline \multicolumn{3}{|c|}{ ulated by authors } \\
\hline
\end{tabular}

\section{CONCLUSIONS}

The research gives us the ground to conclude that:

- modern development of regional economic systems should be based on the key foundations of financial decentralization, namely: clear delineation of functional and expenses liabilities by the levels of authority; expanding the rights and competences of local self-governments in terms of local finances; eliminating the vertical and horizontal misbalances by budget transfers in order to achieve certain standards of social services on the entire territory of the country;

- there are certain doubts that the growth of quantitative decentralization parameters can efficiently transform perspective opportunities of territories into specific tasks of their development. Implementation of internal capacity of regional development is efficient in case of clear decentralization of liabilities and defining each administrative unit's place in the community-region-state format;

- there is no unified model of implementation of financial decentralization reform, same as there is no optimal level of financial decentralization and there are no ideal solutions in the implementation of financial 
decentralization reform, because each country has its own development way. However, each country should aspire to balance the decentralization by various directions: education, healthcare, land management, energy efficiency. Which areas should be more decentralized and which should be less decentralized depends on the capacity of local authorities;

- $\quad$ there are no established methods of measuring the impact of financial decentralization on the development of regional economic systems and a unified set of indicators for assessing decentralization. Our simulation on the example of Ukraine made it possible to identify the problems and factors of growth of regional economic systems. The results we have obtained can serve as a basis for developing a system of measures to improve regional economic policy;

- further financial decentralization reform in Ukraine requires considering challenges in the development of regional economic systems, namely: there is a possibility of disruption and disintegration of economic and social space. Therefore, there is a need to direct the results of financial decentralization into sustainable development of territories. Local taxes and fees should be a reliable financial basis of the long-term development of economic systems, which will contribute to minimizing the transfer dependence of central authorities.

\section{REFERENCES}

11] N. Akai, and M. Sakata, "Fiscal decentralization contributes to economic growth: evidence from state-level cross-section data for the United States", Journal of Urban Economics, vol. 52. no. 1, pp. $93-$ $108,2002$.
[2] J. Lin, and Z. Liu, "Fiscal decentralization and economic growth in China", Economic Development and Cultural Change, vol. 49, no. 1, pp. 1-21, 2000.

[3] J. Boex, and B. Edwards, "The (Mis-) Measurement of Fiscal Decentralization in Developing and Transition Countries: Accounting for Devolved and Nondevolved Local Public Sector Spending", Public Finance Review, vol. 6, no. 44, pp. 788-810, 2016.

[4] B. Edwards, S. Yilmaz, and J. Boex, "Decentralization as a Post'Conflict Strategy: Local Government Discretion and Accountability in Sierra Leone" Public Admin. Dev., no. 35, pp. 46-60, 2015 .

[5] H. Blöchliger, B. Égert, and K. Fredriksen, "Fiscal federalism and its impact on economic activity, public investment and the performance of educational systems", All Economics Department Working Papers are available through OECD's, 2013. [Online]. Available: https://www.oecd-ilibrary.org/docserver/5k4695840w7ben.pdf?expires $=1567004503 \&$ id $=$ id \&accname $=$ guest $\&$ checksum $=9 \mathrm{E} 9$ 44BE0BDF681F037FDECF8E2D507AD

[6] J. Kim, and S. Dougherty, Fiscal Decentralisation and Inclusive Growth in Asia, Paris, OECD Fiscal Federalism Studies, OECD Publishing, 2019.

[7] D. Cantarero, and P. Perez Gonzalez, "Fiscal decentralization and economic growth: Evidence from Spanish regions", Public Budgeting \& Finance, vol. 29, no. 4, pp. 24-44, 2009.

[8] I. Lukyanenko, System modeling of the parameters of budget system in Ukraine: principles and instruments, Kiev: Publishing house "KyevoMohylyanska Academiya", 2004. [in Ukrainian].

[9] A. Ya. Kuznetsova, H. V. Voznyak, and I. V. Zherebylo, "Social and economic effects of inter-budgetary relations' decentralization in Ukraine: assessment and challenges", Financial-Credit Activity: Theory and Practice Problems, vol. 4, no. 27, pp.446-456, 2018. [in Ukrainian].

[10] V. Scepanovic, EU Regional Development Policy in the Accession Countries: Opportunistic Decentralization, Fiscal Risks, and the Premature Death of Multi-Level Governance, Italy, European University Institute Badia Fiesolana, 2016. 